\title{
IC on: Laparoscopic Peritoneal Dialysis Catheter Insertion Using Nitrous Oxide Under Procedural Sedation
}

\author{
Danny Rosin
}

Published online: 16 September 2014

(C) Société Internationale de Chirurgie 2014

Over nearly 30 years of "general surgery" laparoscopy, we have seen many variations to the basic technique, trying to improve, enhance, or simply change the surgeon's intra-op experience, the patient post-op recovery or the overall outcome. Some changes stayed with us, such as reduced diameter scopes and instruments, some proved to be too cumbersome despite good intentions, and disappeared (like gasless abdominal wall lifting [1] to replace $\mathrm{CO}_{2}$ insufflation), and some are still used by enthusiasts but are on their way to oblivion, or at least to the rear end (Single-port anyone? but TAMIS [2] is great.) Alternative gases to achieve pneumoperitoneum were also the focus of many trials [3], trying to overcome the disadvantages of $\mathrm{CO}_{2}$, mainly pain and hypercarbia. Reality has proven $\mathrm{CO}_{2}$ to be the winner, as the "runner-up", nitrous oxide, lost the race due to rumors about risk of intra-abdominal explosion [4] (probably unfounded [5]), and the need for a scavenging system, to protect the OR team from an unnecessary laugh.

In this issue $\mathrm{Wu}$ et al. are reviving this issue [6], and nicely demonstrate the effectiveness of their technique in nearly 90 patients. While laparoscopic placement of peritoneal dialysis catheter [7] is commonly performed, and has some (minor) advantages over the open procedure, it is usually limited to patients who can undergo general anesthesia. The use of nitrous oxide expands the indications to patients for whom general anesthesia is too risky. In order to apply the authors' technique a dedicated gas delivery system is required, and if energy source is needed-the ultrasonic device is used. It appears that open insertion under local anesthesia is therefore still a cheap and simple alternative. Will this article (and other similar studies) reignite (pun intended) the revolution? Knowing the surgical community I have my own doubts.

\section{References}

1. Ren H, Tong Y, Ding XB, Wang X, Jin SQ, Niu XY, Zhao X, Li Q (2014) Abdominal wall-lifting versus CO2 pneumoperitoneum in laparoscopy: a review and meta-analysis. Int J Clin Exp Med. 7(6): 1558-1568 eCollection 2014

2. Albert MR, Atallah SB, deBeche-Adams TC, Izfar S, Larach SW (2013) Transanal minimally invasive surgery (TAMIS) for local excision of benign neoplasms and early-stage rectal cancer: efficacy and outcomes in the first 50 patients. Dis Colon Rectum. 56(3):301-307

3. Menes T, Spivak H (2000) Laparoscopy: searching for the proper insufflation gas. Surg Endosc. 14(11):1050-1056

4. Neuman GG, Sidebotham G, Negoianu E, Bernstein J, Kopman AF, Hicks RG, West ST, Haring L (1993) Laparoscopy explosion hazards with nitrous oxide. Anesthesiology. 78(5):875-879

5. Hunter JG, Staheli J, Oddsdottir M, Trus T (1995) Nitrous oxide pneumoperitoneum revisited. Is there a risk of combustion? Surg Endosc. 9(5):501-504

6. Wu R, Okrainec A, Penner T (2014) Laparoscopic peritoneal dialysis catheter insertion using Nitrous Oxide under procedural sedation. World J Surg. doi:10.1007/s00268-014-2761-2

7. Keshvari A, Najafi I, Jafari-Javid M, Yunesian M, Chaman R, Taromlou MN (2009) Laparoscopic peritoneal dialysis catheter implantation using a Tenckhoff trocar under local anesthesia with nitrous oxide gas insufflation. Am J Surg. 197(1):8-13
D. Rosin $(\bowtie)$

General Surgery \& Transplantation, Sheba Medical Center,

Tel Hashomer, Israel

e-mail: drosin@mac.com 